\title{
Correlation of TERT and Stem Cell Markers in the Context of Human Breast Cancer
}

\author{
UMAR WAZIR $^{1,2}$, MONA M.A.W. ORAKZAI ${ }^{1}$, TRACEY AMANDA MARTIN ${ }^{3}$, \\ WEN G. JIANG ${ }^{3}$ and KEFAH MOKBEL ${ }^{1,2}$ \\ ${ }^{1}$ The London Breast Institute, Princess Grace Hospital, London, U.K.; \\ ${ }^{2}$ Department of General Surgery, Khyber Teaching Hospital, Peshawar, Pakistan; \\ ${ }^{3}$ Cardiff-China Cancer Research Collaboration, \\ Cardiff University School of Medicine, Cardiff University, Cardiff, U.K.
}

\begin{abstract}
Background: Telomerase reverse transcriptase (TERT) has a well-known role in carcinogenesis due to its functions in inducing cell immortality and preventing senescence. In this study, the relationships between TERT and a panel of known stem cell markers was examined in order to direct future enquiries into the role of 'stem-ness' in human breast cancer. Materials and Methods: Breast cancer tissues $(n=124)$ and adjacent normal tissues $(n=30)$ underwent reverse transcription and quantitative polymerase chain reaction. Transcript levels were analyzed for the correlation with that of TERT. Results: A significant direct correlation was found in cancerous tissue between TERT and BMII proto-oncogene polycomb ring finger 4 (BMI1; $n=88, p<0.001)$, nestin (NES; $n=88, p<0.001)$, POU domain, class 5, transcription factor 1 (POU5F1; $n=88, p<0.001)$, aldehyde dehydrogenase 1 family member A2 (ALDH1A2; $n=87, p=0.0298)$, cyclin-dependent kinase inhibitor $1 A(C D K N 1 A ; n=88, p<0.001)$, integrin subunit beta 1 (ITGNB1; $n=88, p<0.001)$, integrin subunit alpha 6 (ITGA6; $n=88, p<0.001)$, cluster of differentiation antigen 24 (CD24; $n=88, p=0.0114)$, MET proto-oncogene (MET; $n=78, p<0.001)$ and noggin (NOG; $n=88, p<0.001)$. Conclusion: The evidence presented in this article of possible interactions between TERT and a discrete subset of known stem cell markers would significantly contribute to further enquiries regarding clonal dynamics in the context of human breast cancer.
\end{abstract}

This article is freely accessible online.

Correspondence to: Professor Kefah Mokbel, London Breast Institute, Princess Grace Hospital, 45 Nottingham Place, London W1U 5NY, U.K. E-mail: kefahmokbel@hotmail.com

Key Words: Telomeres, pluripotency, breast cancer, cell cycle.
Breast cancer continues to be a major cause of pathology in women. It is the most common cause of invasive cancer in females, with two million newly-diagnosed cases worldwide in 2018 (1). It is the second most common cause of cancerrelated mortality for females in the UK, accounting for $15 \%$ of all cancer-related deaths in women in 2016 (2). However, it has to be acknowledged that survival has improved over the past several decades due to advances in treatment (3).

A greater understanding of the molecular pathways underlying breast cancer has been fundamental to many of these advances. The recognition of breast cancer as a diverse collection of diseases characterised by distinct molecular signatures has been an important recent development. This finding was the basis for the recent development of genomic assays for breast cancer, which have greatly improved prognostication and decision-making with regards to adjuvant chemotherapy (4). In addition, this highlights the potential role for tailored treatment of breast cancer on the basis of specific pathways which may be involved (5).

Human telomerase reverse transcriptase (TERT) is a molecule with a role in cell aging and immortality. By virtue of its function, it is expected to have a role in oncogenesis. This was borne out by the results of our previous study, in which we found the mRNA expression of TERT in breast cancer samples to be associated with poor prognosis (6).

Neoplastic lesions, by virtue of their high cellular turnover, have cells which acquire a degree of pluripotency reminiscent of stem cells ('stem-ness'). According to the stem cell theory regarding oncogenesis, such cells may have role in maintaining cellular turnover, and may have a profound implication in the development of tailored and targeted treatments for breast cancer (7).

In this study, we aimed to examine the role of TERT in the context of cancer-related cellular pluripotency by studying the relations of TERT mRNA expression levels in breast cancer samples with a panel of 30 known stem cell marker molecules previously studied in the context of breast cancer (7-9). 


\section{Materials and Methods}

Samples. Tissue samples were collected after informed consent with ethical approval as per contemporaneous institutional guidelines (Bro Taf Health Authority ethics approval numbers 01/4303 and 01/4046). Immediately after surgical excision, a tumour sample was taken from the tumour area. Another was taken from the background non-cancerous tissue within $2 \mathrm{~cm}$ of the tumour, without affecting the assessment of tumour margins in order to serve as controls for comparison with the cancerous tissue. Breast cancer tissues $(n=124)$ and normal background tissues $(n=33)$ were collected and stored at $-80^{\circ} \mathrm{C}$ in liquid nitrogen until analysis. This cohort has been the subject of a number of completed and on-going studies $(6,10,11)$.

All the patients were treated according to local guidelines, following discussions in multidisciplinary meetings (12). Patients undergoing breast-conserving surgery also underwent radiotherapy. Patients with hormone-sensitive disease were given tamoxifen. Hormone-insensitive cases, high-grade cancer, and node-positive cases were treated with adjuvant therapy. Clinicopathological data (Table I) were collected from the patient charts and collated in an encrypted database $(7,13)$.

Tissue processing, RNA extraction and cDNA synthesis. RNA extraction kits and reverse transcription kits were obtained from AbGene Ltd. (Epsom Surrey, UK). Custom made hot-start Master Mix for quantitative polymerase chain reaction (qPCR) was from AbGene Ltd (Epsom, Surrey, UK).

The literature was reviewed to identify known stem cell markers which were included in the panel of molecules studied for correlations with TERT: 30 were selected in all. They are enumerated in Table II (14-40).

Approximately $10 \mathrm{mg}$ of cancerous tissue was homogenised. A larger amount of matched normal tissue $(20-50 \mathrm{mg})$ was used as its high fat content made it difficult to obtain sufficient RNA for analysis. The concentration of RNA was determined using a UV spectrophotometer (Wolf Laboratories, York, UK) to ensure adequate amounts of RNA for analysis. Reverse transcription was carried out using a reverse transcription kit (AbGene) with an anchored olig (dT) primer using $1 \mathrm{mg}$ of total RNA in a 96-well plate to produce cDNA. The quality of cDNA was verified using $\beta$ actin primers (primers 5'-ATGATATCGCCGCGCTCGTC-3' and 5'CGCTCGGTGAGGATCTTCA-3’) (7, 13).

Quantitative analysis. Transcripts of cDNA library were determined using real-time qPCR based on Amplifluor technology. The PCR primers were designed using Beacon Designer software (Premier Biosoft International Ltd., Palo Alto, CA, USA), but an additional sequence, known as the $Z$ sequence (5'-ACTGAACCTGA CCGTACA-3'), which is complementary to the universal $\mathrm{Z}$ probe (Intergen Inc., Oxford, UK) was added to the primer. The primers were synthesized by Invitrogen Ltd. (Paisley, UK).

The reaction was carried out under the following conditions: $94^{\circ} \mathrm{C}$ for $12 \mathrm{~min}$ and 50 cycles of $94^{\circ} \mathrm{C}$ for $15 \mathrm{~s}, 55^{\circ} \mathrm{C}$ for $40 \mathrm{~s}$, and $72^{\circ} \mathrm{C}$ for $20 \mathrm{~s}$. The levels of each transcript were generated from a standard that was simultaneously amplified within the samples. Levels of expressions of the molecules being studied were normalised against cytokeratin 19 (CK19).

With every PCR run, a negative and positive control was employed, using a known cDNA sequence (podoplanin) $(7,13)$.
Table I. Description of clinical cohort.

\begin{tabular}{lc}
\hline Parameter & Number of samples \\
\hline Tissue type & \\
Background, normal & 30 \\
Tumour & 124 \\
Tumour grade & \\
1 & 24 \\
2 & 42 \\
3 & 58 \\
Nottingham prognostic index & \\
Grade 1 & 68 \\
Grade 2 & 38 \\
Grade 3 & 16 \\
Unknown & 2 \\
TNM Stage & \\
1 & 70 \\
2 & 40 \\
3 & 7 \\
4 & 4 \\
Unknown & 3 \\
Histology & \\
Ductal & 94 \\
Lobular & 14 \\
Other & 16 \\
Patient outcome & \\
Alive and well & 75 \\
Metastatic disease & 27 \\
Death from breast cancer & \\
All poor outcomes (Metastatic disease & \\
and disease-related mortality) & \\
\hline
\end{tabular}

TNM: Tumour, node and metastases staging (12).

The samples were selected out of a cohort of 124 samples. However, some samples had to be excluded due to spurious results caused by depletion of the sample or issues with pipetting or the apparatus.

Statistical analysis. Correlations between TERT and molecules on the stem cell panel was performed using the SigmaPlot 11 statistical software package (Systat Software Inc., Hounslow, UK). Correlations were studied using the Spearman rank correlation test. The transcript levels of stem-cell related molecules within the breast cancer specimens were compared to the mRNA expression of TERT. All samples in the cohort were included. However, some specimens had to be excluded due to spurious results caused by depletion of the sample or due to errors in the PCR readings due to pipetting errors.

Correlations with $p$-Values less than 0.05 were considered significant.

\section{Results}

Spearman rank correlation test showed that TERT had significant direct correlations with the expressions of BMI1 proto-oncogene polycomb ring finger $4(B M I 1 ; \mathrm{r}=0.581, \mathrm{n}=88, p<0.001)$, nestin (NES; $\mathrm{r}=0.581, \mathrm{n}=88, p<0.001)$, POU domain, class 5, transcription factor 1 (POU5F1; $\mathrm{r}=651, \mathrm{n}=88, p<0.001$ ), aldehyde dehydrogenase 1 family member A2 (ALDH1A2; 
Table II. Correlations of mRNA expression (normalised to that cytokeratin 19) of stem cell markers with that of telomerase reverse transcriptase (TERT) by the Spearman rank correlation test.

\begin{tabular}{|c|c|c|c|c|c|}
\hline Gene symbol & Molecule encoded & $\begin{array}{l}\text { Correlation } \\
\text { coefficient }(\mathrm{R})\end{array}$ & $p$-Value & $\begin{array}{c}\text { No. of } \\
\text { samples }\end{array}$ & Citation \\
\hline$C D 24$ & Cluster of differentiation 24 & 0.269 & 0.0114 & 88 & $(16)$ \\
\hline ITGB1 & Integrin subunit beta 1 & 0.476 & 0.0000034 & 88 & (16) \\
\hline$C D 44$ & Cluster of differentiation 44 & -0.0185 & 0.861 & 91 & (17) \\
\hline ITGA6 & Integrin subunit alpha 6 & 0.663 & 0.0000002 & 88 & (16) \\
\hline BMII & BMI1 proto-oncogene polycomb ring finger 4 & 0.581 & 0.0000000014 & 88 & (18) \\
\hline$N E S$ & Nestin & 0.581 & 0.0000000013 & 88 & (19) \\
\hline POU5F1 & POU domain, class 5, transcription factor 1 . & 0.651 & 0.0000002 & 88 & (20) \\
\hline$A L D H 1 A 2$ & Aldehyde dehydrogenase 1 family member A2 & 0.233 & 0.0298 & 87 & $(21)$ \\
\hline MET & MET proto-oncogene & 0.591 & 0.000000016 & 76 & (23) \\
\hline CDKN1A & Cyclin-dependent kinase inhibitor $1 \mathrm{~A}$ & 0.611 & 0.0000002 & 88 & (24) \\
\hline$N O G$ & Noggin. & 0.421 & 0.0000311 & 93 & (22) \\
\hline$C D 34$ & Cluster of differentiation 34 & -0.0093 & 0.931 & 88 & (23) \\
\hline$C D C P 1$ & CUB domain-containing protein 1. & 0.119 & 0.268 & 88 & (25) \\
\hline THY1 & Thymocyte differentiation antigen 1 , or CD90. & 0.143 & 0.206 & 80 & (26) \\
\hline$A L D H 1 A 1$ & Aldehyde dehydrogenase 1 family member A 1 . & 0.0788 & 0.483 & 81 & (21) \\
\hline$A L D H 1 A 3$ & Aldehyde dehydrogenase 1 family member A3. & -0.0177 & 0.888 & 65 & $(21)$ \\
\hline$A L D H 1 B 1$ & Aldehyde dehydrogenase 1 family member B1. & -0.0871 & 0.416 & 89 & (27) \\
\hline$L M N A / C$ & Lamin A/C & 0.0884 & 0.396 & 94 & (28) \\
\hline$L M N B 1$ & Lamin B1. & -0.19 & 0.067 & 94 & $(28)$ \\
\hline$N R P 1$ & Neuropilin 1 & 0.197 & 0.066 & 88 & (29) \\
\hline$N R P 2$ & Neuropilin 2. & -0.0796 & 0.46 & 88 & $(30)$ \\
\hline PMSA2 & Proteasome (prosome, macropain) subunit, alpha type, 2 & 0.0772 & 0.466 & 91 & $(31)$ \\
\hline FLT1 & Fms-related tyrosine kinase 1 & 0.0247 & 0.818 & 89 & $(32)$ \\
\hline$K D R$ & Kinase insert domain receptor & 0.0173 & 0.872 & 89 & (33) \\
\hline FLT4 & Fms-related tyrosine kinase 4 & 0.033 & 0.753 & 93 & (34) \\
\hline SNAI1 & Snail family transcriptional repressor 1 & 0.0996 & 0.381 & 79 & $(35)$ \\
\hline SNAI2 & Snail family transcriptional repressor 2 & 0.0352 & 0.74 & 91 & (35) \\
\hline TWIST1 & Twist family bHLH transcription factor 1. & -0.0641 & 0.548 & 90 & (36) \\
\hline SELL & Selectin L & 0.0105 & 0.927 & 78 & (37) \\
\hline SELE & Selectin E & -0.158 & 0.165 & 79 & (37) \\
\hline SELP & Selectin P. & -0.0961 & 0.396 & 80 & $(37)$ \\
\hline $\mathrm{NOTCH} 2$ & Notch receptor 2 & -0.0981 & 0.354 & 91 & $(38)$ \\
\hline NOTCH1 & Notch receptor 1 & 0.044 & 0.675 & 93 & (38) \\
\hline PECAM1 & Platelet endothelial cell adhesion molecule 1. & 0.0484 & 0.651 & 89 & (39) \\
\hline STAT5 & Signal transducer and activator of transcription 5 & -0.0296 & 0.782 & 90 & (40) \\
\hline CD133 & Cluster of differentiation 133 & 0.149 & 0.172 & 86 & (23) \\
\hline
\end{tabular}

$\mathrm{r}=0.233, \mathrm{n}=87, p=0.0298)$, Cyclin dependent kinase inhibitor $1 \mathrm{~A}$ (CDKN1A; $\mathrm{r}=0.611, \mathrm{n}=88, p<0.001)$, integrin subunit beta 1 (ITGNB1; $\mathrm{r}=0.476, \mathrm{n}=88, p<0.001$ ), Integrin subunit alpha 6 (ITGNA6; $\mathrm{r}=0.663, \mathrm{n}=88, p<0.001$ ), cluster of differentiation antigen 24 (CD24; $\mathrm{r}=0.269, \mathrm{n}=88, p=0.0114)$, MET protooncogene (MET; $\mathrm{r}=0.591, \mathrm{n}=78, p<0.001)$ and NOGGIN (NOG; $\mathrm{r}=0.421, \mathrm{n}=88, p<0.001$ ) (Table II).

\section{Discussion}

Telomeres are the straight portions at the end of a chromosome and are composed of repeating segments of nucleotides. During mitosis, DNA polymerase is unable to replicate this portion of the genome, which leads to genomic instability and senescence. The telomeres are repaired by a specialised enzyme referred to as TERT, which is a multimeric molecule resident in the nucleus (41). TERT enables the cell to continue to proliferate without undergoing senescence, thereby achieving cell immortality (42).

Cell immortality represents an important gain of function for neoplastic cells. Indeed 70-90\% of neoplastic lesions and cancer cell lines surveyed in one study were found to have increased activity of TERT (43). In another study, Elkak et al. found high mRNA expression of TERT to be associated with poorer outcomes in human breast cancer (6). Telomerelengthening, with consequent replicative immortality has been characterised as a prerequisite for oncogenesis, with TERT-mediated telomere lengthening being identified as a 
factor in $85-90 \%$ of cancers types, with alternative pathways accounting for the remainder (43). However, recent evidence has suggested that in addition to telomere lengthening, TERT may have a role in endothelial-mesenchymal transformation, as well as in the induction of stemness $(44,45)$.

Classically, it was believed that tumours consisted of uniformly neoplastic cells capable of proliferating independently, and giving rise to new clonal lineages which may contribute to the emergence of therapeutic resistance or to relapse of the disease after the end of adjuvant therapy. This has been referred to as the clonal evolution model, and was initially elucidated in 1976 by Nowell (46). The high degree of allelic heterogeneity seen in cancerous cells within solid tumours and in situ lesions is believed to be due to clonal neoplastic expansion, as would be predicted by the clonal evolutionary model $(47,48)$.

However, over the past three decades, evidence has been cited in favour of a tumour progression model which posits a hierarchy among the clonal lineages, privileging a small sub-population of pluripotential cells with known stem cell markers. This has been labelled as the cancer stem-cell (CSC) hypothesis. This was initially described by Bonnet and Dick in 1997 in the context of acute myelogenous leukaemia (49). In 2003, Al Hajj et al. showed that all cells within a solid breast tumour were not capable of generating a tumour when injected into nonobese diabetic/severe combined immunodeficiency (NOD/SCID) mice, and identified cells with a $\mathrm{CD} 44^{+} / \mathrm{CD} 24^{-}$phenotype to be capable of pluripotential differentiation (50). Subsequently, CSCs were identified in melanoma (51), and neoplasias of the brain (52), lung (53), prostate (54) and colon (55). Other markers, most significantly acetaldehyde dehydrogenase 1 (ALDH1), have also been identified (56).

Whilst both of these hypotheses have broad similarities, they have very varied and mutually exclusive clinical implications, particularly with regards to treatment of relapsing disease and therapeutic resistance. Most current treatment modalities target proliferating cells indiscriminatingly. Such an approach would be expected to select clonal lineages more likely to be resistant to treatment, and potentially result in relapse in the disease after adjuvant treatment (57). However, if a progenitor population of pluripotential cells is positively identified, it would provide a discrete therapeutic target whose obliteration could potentially reverse the pathology (58).

However, issues have arisen with regards to the purported role of CSCs. There has been a failure in consistent replication of findings. There have been queries whether immunodeficient mice provide a suitable microenvironment to replicate in vivo conditions of human cancer (57). Furthermore, the use of proteolytic enzymes in the processing of tumours before sorting by flow cytometry has been cited as a destructive process which may affect the quality and reliability of the samples studied $(57,59)$.
Being that as it may, the mRNA expression levels of stem cell markers, such as $C D 44$ and $A L D H 1$, have been found to be predictive of poor prognosis in breast carcinoma, suggesting that so-called 'stem-ness' is likely to have a role in solid tumours $(56,60)$.

More recently, it has been suggested that a viable model of tumour progression would be midway between clonal evolution and stem cell-based clonal hierarchy, likely with certain clonal lineages acquiring stem cell-like qualities under certain conditions (15).

By examining the association between known stem cell markers and TERT, we hope to link two highly influential concepts regarding our understanding of oncogenesis. By stratifying the multitude of stem cell markers by their correlation with TERT, an oncogenic molecule for which the evidence base has attained a degree of maturity, we hope to have provided an addition avenue of enquiry for research in breast tumour heterogeneity and clonal dynamics. This knowledge would hopefully enable more tailored treatments for recurrent and relapsing disease.

Several of the molecules identified in our study have been shown to have roles in oncogenesis. Prominent among these is POU5F1 (better known as OCT4), which has been identified as an essential transcription factor mediating stem-ness. Shen and colleagues studied the effects of overexpression of POU5F1 in MDA-MB-231 and 4T1 breast cancer cell lines, and found that the overexpression of POU5F1 suppressed migration and invasion in these usually aggressive cell types (20).

NES has been identified as a marker of poor prognosis in ovarian (61), breast (62) and pancreatic (63) neoplasia. CD24, CD29 and CD44 have been studied as markers for colonic CSCs (64). BMI1 has been shown to have a role in mediating bone metastasis in breast cancer $(18,65)$. Similarly, evidence of a role in cancer has been suggested in the literature for the molecules identified as interacting with TERT in this study $(8,9)$.

However, certain limitations have to be acknowledged in our study. We were limited to mRNA expression data for a cohort for which we do not have information regarding protein expression. Furthermore, in vitro studies in transfected cell lines would be required to better characterise the effects of knocked-down and ectopic expression of these molecules, as well as to be able to delineate the interactions which may mediate their effects. By highlighting this subset of stem cell markers and their relation with TERT, we believe we have identified a potentially important direction of enquiry in understanding the role of stem-ness in breast cancer.

\section{Conclusion}

CSCs continue to be an important if challenging research question. An understanding of their role in tumour progression would go a long way in enabling more tailored treatments of 
human breast cancer. We believe that the evidence we presented in this article of possible interactions between TERT and a discrete subset of known stem cell markers would significantly contribute to further enquiries regarding clonal dynamics in the context of human breast cancer.

\section{Acknowledgements}

This study was funded by grants from the Breast Cancer Hope Foundation (London, UK).

\section{Conflicts of Interest}

The Authors have no conflicts of interest to report.

\section{Authors' Contributions}

The study was initiated and designed by KM and WGJ. TAM \& WGJ conducted the qPCR assays. WGJ curated the database and performed the data analysis. UW performed the literature review and drafted the manuscript. KM \& MWO proof-read the manuscript. MWO constructed the tables.

\section{References}

1 World Cancer Research Fund: Breast cancer statistics. London, UK, 2018. url: https://www.wcrf.org/dietandcancer/cancertrends/breast-cancer-statistics Accessed 2018.

2 Cancer Research UK: Cancer mortality for common cancers. London, UK, 2018. url: https://www.cancerresearchuk.org/ health-professional/cancer-statistics/mortality/common-cancerscompared Accessed 2018.

3 Narod SA, Iqbal J and Miller AB: Why have breast cancer mortality rates declined? J Cancer Policy 5: 8-17, 2015. DOI: 10.1016/j.jcpo.2015.03.002.

4 Wazir U, Mokbel K, Carmichael A and Mokbel K: Are online prediction tools a valid alternative to genomic profiling in the context of systemic treatment of ER-positive breast cancer? Cell Mol Biol Lett 22: 20, 2017. PMID: 28878809. DOI: 10.1186/ s11658-017-0049-x.

5 Tang G, Shak S, Paik S, Anderson SJ, Costantino JP, Geyer CE, Jr., Mamounas EP, Wickerham DL and Wolmark N: Comparison of the prognostic and predictive utilities of the 21-gene Recurrence Score assay and Adjuvant! for women with nodenegative, ER-positive breast cancer: results from NSABP B-14 and NSABP B-20. Breast Cancer Res Treat 127: 133-142, 2011. PMID: 21221771. DOI: 10.1007/s10549-010-1331-z.

6 Elkak A, Mokbel R, Wilson C, Jiang WG, Newbold RF and Mokbel K: hTERT mRNA expression is associated with a poor clinical outcome in human breast cancer. Anticancer Res 26: 4901-4904, 2006. PMID: 17214359.

7 Martin TA and Jiang WG: Evaluation of the expression of stem cell markers in human breast cancer reveals a correlation with clinical progression and metastatic disease in ductal carcinoma. Oncol Rep 31: 262-272, 2014. PMID: 24173498. DOI: 10.3892/ or.2013.2813.

8 Wang T, Shigdar S, Gantier MP, Hou Y, Wang L, Li Y, Shamaileh HA, Yin W, Zhou SF, Zhao X and Duan W: Cancer stem cell targeted therapy: progress amid controversies. Oncotarget 6: 44191-44206, 2015. PMID: 26496035. DOI: 10.18632/oncotarget.6176.

9 Dawood S, Austin L and Cristofanilli M: Cancer stem cells: implications for cancer therapy. Oncology 28: 1101-1107, 1110, 2014. PMID: 25510809.

10 Al Sarakbi W, Sasi W, Jiang WG, Roberts T, Newbold RF and Mokbel K: The mRNA expression of SETD2 in human breast cancer: correlation with clinico-pathological parameters. BMC Cancer 9: 290, 2009. PMID: 19698110. DOI: 10.1186/14712407-9-290.

11 Wazir U, Jiang WG, Sharma AK and Mokbel K: The mRNA expression of DAP3 in human breast cancer: correlation with clinicopathological parameters. Anticancer Res 32: 671-674, 2012. PMID: 22287761.

12 Hermanek P and Sobin L: TNM Classification of Malignant Tumours. Springer Berlin Heidelberg, Berlin, Heidelberg, 1987.

13 Jiang WG, Watkins G, Lane J, Cunnick GH, Douglas-Jones A, Mokbel K and Mansel RE: Prognostic value of rho GTPases and rho guanine nucleotide dissociation inhibitors in human breast cancers. Clin Cancer Res 9: 6432-6440, 2003. PMID: 14695145.

14 Campbell HE, Gray AM, Harris AL, Briggs AH and Taylor MA: Estimation and external validation of a new prognostic model for predicting recurrence-free survival for early breast cancer patients in the UK. Br J Cancer 103: 776-786, 2010. PMID: 20823886. DOI: 10.1038/sj.bjc.6605863.

15 Kakarala M and Wicha MS: Implications of the cancer stem-cell hypothesis for breast cancer prevention and therapy. J Clin Oncol 26: 2813-2820, 2008. PMID: 18539959. DOI: 10.1200/ JCO.2008.16.3931.

16 Stingl J, Eirew P, Ricketson I, Shackleton M, Vaillant F, Choi D, Li HI and Eaves CJ: Purification and unique properties of mammary epithelial stem cells. Nature 439: 993-997, 2006. PMID: 16395311. DOI: 10.1038/nature04496.

17 Abraham BK, Fritz P, McClellan M, Hauptvogel P, Athelogou $\mathrm{M}$ and Brauch $\mathrm{H}$ : Prevalence of CD44+/CD24-/low cells in breast cancer may not be associated with clinical outcome but may favor distant metastasis. Clin Cancer Res 11: 1154-1159, 2005. PMID: 15709183.

18 Srinivasan M, Bharali DJ, Sudha T, Khedr M, Guest I, Sell S, Glinsky GV and Mousa SA: Downregulation of BMII in breast cancer stem cells suppresses tumor growth and proliferation. Oncotarget 8: 38731-38742, 2017. PMID: 28418883. DOI: 10.18632/oncotarget.16317.

19 Matsuda Y, Yoshimura H, Ueda J, Naito Z, Korc M and Ishiwata T: Nestin delineates pancreatic cancer stem cells in metastatic foci of NOD/Shi-SCID IL2Rgamma(null) (NOG) mice. Am J Pathol 184: 674-685, 2014. PMID: 24412093. DOI: 10.1016/ j.ajpath.2013.11.014.

20 Shen L, Qin K, Wang D, Zhang Y, Bai N, Yang S, Luo Y, Xiang $\mathrm{R}$ and Tan X: Overexpression of OCT4 suppresses the metastatic potential of breast cancer cells via RND1 downregulation. Biochim Biophys Acta 1842: 2087-2095, 2014. PMID: 25068817. DOI: 10.1016/j.bbadis.2014.07.015

21 Flahaut M, Jauquier N, Chevalier N, Nardou K, Balmas Bourloud K, Joseph JM, Barras D, Widmann C, Gross N, Renella R and Muhlethaler-Mottet A: Aldehyde dehydrogenase activity plays a key role in the aggressive phenotype of neuroblastoma. BMC Cancer 16: 781, 2016. PMID: 27724856. DOI: $10.1186 / \mathrm{s} 12885-016-2820-1$. 
22 Sun XK, Zhou J, Zhang L, Ma T, Wang YH, Yang YM, Tang YT, Li H and Wang LJ: Down-regulation of Noggin and miR138 coordinately promote osteogenesis of mesenchymal stem cells. J Mol Histol 48: 427-436, 2017. PMID: 29094227. DOI: 10.1007/s10735-017-9740-5.

23 Oshima Y, Suzuki A, Kawashimo K, Ishikawa M, Ohkohchi N and Taniguchi $\mathrm{H}$ : Isolation of mouse pancreatic ductal progenitor cells expressing CD133 and c-MET by flow cytometric cell sorting. Gastroenterology 132: 720-732, 2007. PMID: 17258722. DOI: $10.1053 /$ j.gastro.2006.11.027.

24 Zhang XR, Liu YA, Sun F, Li H, Lei SW and Wang JF: p21 is responsible for ionizing radiation-induced bypass of mitosis. Biomed Environ Sci 29: 484-493, 2016. PMID: 27554118. DOI: 10.3967/bes2016.064.

25 Gao W, Chen L, Ma Z, Du Z, Zhao Z, Hu Z and Li Q: Isolation and phenotypic characterization of colorectal cancer stem cells with organ-specific metastatic potential. Gastroenterology 145 : 636-646 e635, 2013. PMID: 23747337. DOI: 10.1053/ j.gastro.2013.05.049.

26 Shaikh MV, Kala M and Nivsarkar M: CD90 a potential cancer stem cell marker and a therapeutic target. Cancer Biomark 16: 301-307, 2016. PMID: 27062695. DOI: 10.3233/CBM-160590.

27 Singh S, Arcaroli J, Chen Y, Thompson DC, Messersmith W, Jimeno A and Vasiliou V: ALDH1B1 is crucial for colon tumorigenesis by modulating WNT/beta-catenin, Notch and PI3K/AKT signaling pathways. PLoS One 10: e0121648, 2015. PMID: 25950950. DOI: 10.1371/journal.pone.0121648.

28 Underwood JM, Becker KA, Stein GS and Nickerson JA: The ultrastructural signature of human embryonic stem cells. J Cell Biochem 118: 764-774, 2017. PMID: 27632380. DOI: 10.1002/ jcb. 25736.

29 Grun D, Adhikary G and Eckert RL: VEGF-A acts via neuropilin1 to enhance epidermal cancer stem cell survival and formation of aggressive and highly vascularized tumors. Oncogene 35: 43794387, 2016. PMID: 26804163. DOI: 10.1038/onc.2015.507.

30 Wiszniak S, Scherer M, Ramshaw H and Schwarz Q: Neuropilin-2 genomic elements drive CRE recombinase expression in primitive blood, vascular and neuronal lineages. Genesis 53: 709-717, 2015. PMID: 26454009. DOI: 10.1002/ dvg.22905.

31 Yue W, Sun LY, Li CH, Zhang LX and Pei XT: Screening and identification of ovarian carcinomas related genes. Ai Zheng 23: 141-145, 2004. PMID: 14960231 (in Chinese).

32 Huang Y, Huang Y, Liu D, Wang T and Bai G: Flt-1-positive cells are cancer-stem like cells in colorectal carcinoma. Oncotarget 8: 76375-76384, 2017. PMID: 29100318. DOI: 10.18632/oncotarget.19403.

33 Wu HB, Yang S, Weng HY, Chen Q, Zhao XL, Fu WJ, Niu Q, Ping YF, Wang JM, Zhang $\mathrm{X}$, Yao $\mathrm{XH}$ and Bian $\mathrm{XW}$ : Autophagy-induced KDR/VEGFR-2 activation promotes the formation of vasculogenic mimicry by glioma stem cells. Autophagy 13: 1528-1542, 2017. PMID: 28812437. DOI: 10.1080/15548627.2017.1336277.

34 Gauvrit S, Villasenor A, Strilic B, Kitchen P, Collins MM, Marin-Juez R, Guenther S, Maischein HM, Fukuda N, Canham MA, Brickman JM, Bogue CW, Jayaraman PS and Stainier DYR: HHEX is a transcriptional regulator of the VEGFC/FLT4/PROX1 signaling axis during vascular development. Nat Commun 9: 2704, 2018. PMID: 30006544. DOI: $10.1038 / \mathrm{s} 41467-018-05039-1$.
35 Katoh M and Katoh M: Comparative genomics on SNAI1, SNAI2, and SNAI3 orthologs. Oncol Rep 14: 1083-1086, 2005. PMID: 16142376.

36 Liang Y, Hu J, Li J, Liu Y, Yu J, Zhuang X, Mu L, Kong X, Hong D, Yang Q and Hu G: Epigenetic activation of TWIST1 by MTDH promotes cancer stem-like cell traits in breast cancer. Cancer Res 75: 3672-3680, 2015. PMID: 26141861. DOI: 10.1158/0008-5472.CAN-15-0930.

37 Laubli $\mathrm{H}$ and Borsig L: Selectins promote tumor metastasis. Semin Cancer Biol 20: 169-177, 2010. PMID: 20452433. DOI: 10.1016/j.semcancer.2010.04.005.

38 Takebe N, Miele L, Harris PJ, Jeong W, Bando H, Kahn M, Yang SX and Ivy SP: Targeting Notch, Hedgehog, and WNT pathways in cancer stem cells: clinical update. Nat Rev Clin Oncol 12: 445-464, 2015. PMID: 25850553. DOI: 10.1038/ nrclinonc.2015.61.

39 Gargett CE, Schwab KE, Zillwood RM, Nguyen HP and Wu D: Isolation and culture of epithelial progenitors and mesenchymal stem cells from human endometrium. Biol Reprod 80: 11361145, 2009. PMID: 19228591. DOI: 10.1095/biolreprod. 108.075226.

40 Lv C, Li F, Li X, Tian Y, Zhang Y, Sheng X, Song Y, Meng Q, Yuan S, Luan L, Andl T, Feng X, Jiao B, Xu M, Plikus MV, Dai X, Lengner C, Cui W, Ren F, Shuai J, Millar SE and Yu Z: MiR-31 promotes mammary stem cell expansion and breast tumorigenesis by suppressing WNT signaling antagonists. Nat Commun 8: 1036, 2017. PMID: 29051494. DOI: 10.1038/s41467-017-01059-5.

41 Bryan TM and Reddel RR: Telomere dynamics and telomerase activity in in vitro immortalised human cells. Eur J Cancer 33: 767-773, 1997. PMID: 9282115. DOI: 10.1016/S0959-8049(97) 00065-8.

42 Zhu J, Wang H, Bishop JM and Blackburn EH: Telomerase extends the lifespan of virus-transformed human cells without net telomere lengthening. Proc Natl Acad Sci USA 96: 37233728, 1999. PMID: 10097104.

43 Shay JW and Bacchetti S: A survey of telomerase activity in human cancer. Eur J Cancer 33: 787-791, 1997. PMID: 9282118. DOI: 10.1016/S0959-8049(97)00062-2.

44 Liu Z, Li Q, Li K, Chen L, Li W, Hou M, Liu T, Yang J, Lindvall C, Bjorkholm M, Jia J and Xu D: Telomerase reverse transcriptase promotes epithelial-mesenchymal transition and stem cell-like traits in cancer cells. Oncogene 32: 4203-4213, 2013. PMID: 23045275. DOI: 10.1038/onc.2012.441.

45 Hannen R and Bartsch JW: Essential roles of telomerase reverse transcriptase hTERT in cancer stemness and metastasis. FEBS Lett 592: 2023-2031, 2018. PMID: 29749098. DOI: 10.1002/ 1873-3468.13084.

46 Nowell PC: The clonal evolution of tumor cell populations. Science 194: 23-28, 1976. PMID: 959840.

47 Fujii H, Szumel R, Marsh C, Zhou W and Gabrielson E: Genetic progression, histological grade, and allelic loss in ductal carcinoma in situ of the breast. Cancer Res 56: 5260-5265, 1996. PMID: 8912866.

48 Boland CR, Sato J, Appelman HD, Bresalier RS and Feinberg AP: Microallelotyping defines the sequence and tempo of allelic losses at tumour suppressor gene loci during colorectal cancer progression. Nat Med 1: 902-909, 1995. PMID: 7585215.

49 Bonnet D and Dick JE: Human acute myeloid leukemia is organized as a hierarchy that originates from a primitive hematopoietic cell. Nat Med 3: 730-737, 1997. PMID: 9212098. 
50 Al-Hajj M, Wicha MS, Benito-Hernandez A, Morrison SJ and Clarke MF: Prospective identification of tumorigenic breast cancer cells. Proc Natl Acad Sci USA 100: 3983-3988, 2003. PMID: 12629218. DOI: 10.1073/pnas.0530291100.

51 Fang D, Nguyen TK, Leishear K, Finko R, Kulp AN, Hotz S, Van Belle PA, Xu X, Elder DE and Herlyn M: A tumorigenic subpopulation with stem cell properties in melanomas. Cancer Res 65: 9328-9337, 2005. PMID: 16230395. DOI: 10.1158/ 0008-5472.CAN-05-1343.

52 Singh SK, Clarke ID, Terasaki M, Bonn VE, Hawkins C, Squire J and Dirks PB: Identification of a cancer stem cell in human brain tumors. Cancer Res 63: 5821-5828, 2003. PMID: 14522905.

53 Kim CF, Jackson EL, Woolfenden AE, Lawrence S, Babar I, Vogel S, Crowley D, Bronson RT and Jacks T: Identification of bronchioalveolar stem cells in normal lung and lung cancer. Cell 121: 823-835, 2005. PMID: 15960971. DOI: 10.1016/ j.cell.2005.03.032.

54 Patrawala L, Calhoun T, Schneider-Broussard R, Li H, Bhatia B, Tang S, Reilly JG, Chandra D, Zhou J, Claypool K, Coghlan L and Tang DG: Highly purified CD44+ prostate cancer cells from xenograft human tumors are enriched in tumorigenic and metastatic progenitor cells. Oncogene 25: 1696-1708, 2006 PMID: 16449977. DOI: 10.1038/sj.onc.1209327.

55 Ricci-Vitiani L, Lombardi DG, Pilozzi E, Biffoni M, Todaro M, Peschle $\mathrm{C}$ and De Maria R: Identification and expansion of human colon-cancer-initiating cells. Nature 445: 111-115, 2007. PMID: 17122771 . DOI: 10.1038/nature05384.

56 Ginestier C, Hur MH, Charafe-Jauffret E, Monville F, Dutcher J, Brown M, Jacquemier J, Viens P, Kleer CG, Liu S, Schott A, Hayes D, Birnbaum D, Wicha MS and Dontu G: ALDH1 is a marker of normal and malignant human mammary stem cells and a predictor of poor clinical outcome. Cell Stem Cell 1: 555567, 2007. PMID: 18371393. DOI: 10.1016/j.stem.2007.08.014.

57 Campbell LL and Polyak K: Breast tumor heterogeneity: cancer stem cells or clonal evolution? Cell Cycle 6: 2332-2338, 2007. PMID: 17786053. DOI: 10.4161/cc.6.19.4914.

58 Dick JE: Breast cancer stem cells revealed. Proc Natl Acad Sci USA 100: 3547-3549, 2003. PMID: 12657737. DOI: 10.1073/ pnas. 0830967100 .
59 Hill RP: Identifying cancer stem cells in solid tumors: Case not proven. Cancer Res 66: 1891-1895; discussion 1890, 2006. PMID: 16488984. DOI: 10.1158/0008-5472.CAN-05-3450.

60 Ahmed MA, Aleskandarany MA, Rakha EA, Moustafa RZ, Benhasouna A, Nolan C, Green AR, Ilyas M and Ellis IO: A CD44(-)/CD24(+) phenotype is a poor prognostic marker in early invasive breast cancer. Breast Cancer Res Treat 133: 979-995, 2012. PMID: 22119938. DOI: 10.1007/s10549-011-1865-8.

61 Czekierdowski A, Stachowicz N, Czekierdowska S, Lozinski T, Gurynowicz G and Kluz T: Prognostic significance of TEM7 and nestin expression in women with advanced high grade serous ovarian cancer. Ginekol Pol 89: 135-141, 2018. PMID: 29664548. DOI: 10.5603/GP.a2018.0023.

62 Nowak A and Dziegiel P: Implications of nestin in breast cancer pathogenesis (Review). Int J Oncol 53: 477-487, 2018. PMID: 29901100. DOI: 10.3892/ijo.2018.4441.

63 Ishiwata T, Matsuda Y, Yoshimura H, Sasaki N, Ishiwata S, Ishikawa N, Takubo K, Arai T and Aida J: Pancreatic cancer stem cells: features and detection methods. Pathol Oncol Res 24: 797805, 2018. PMID: 29948612. DOI: 10.1007/s12253-018-0420-x.

64 Kemper K, Grandela C and Medema JP: Molecular identification and targeting of colorectal cancer stem cells. Oncotarget 1: 387-395, 2010. PMID: 21311095. DOI: 10.18632/ oncotarget.101003.

65 Najar M, Fayyad-Kazan H, Faour WH, Badran B, Journe F and Lagneaux L: Breast cancer cells and bone marrow mesenchymal stromal cells: a regulated modulation of the breast tumor in the context of immune response. Inflamm Res 66: 129-139, 2017. PMID: 27783097. DOI: 10.1007/s00011-016-1000-8.
Received January 29, 2019

Revised February 24, 2019

Accepted February 26, 2019 